UC-940

Issued: November 1996

Technical Basis for Storage

of Elastomer-Sealed Produce Cans

in the DOE-STD-3013-94 Package

David R. Horrell

J. L. Stakebake*

R. W. Szempruch ${ }^{* *}$

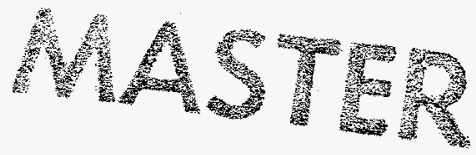

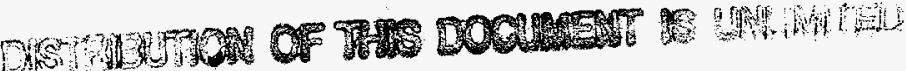

* Science Applications International Corporation, Rocky Flats Office, Golden, CO 80402.

**Westinghouse Hanford Company, Richland, WA 99352. 


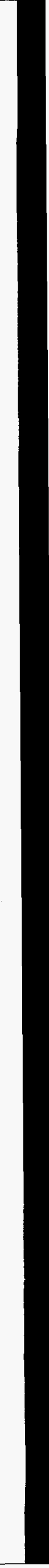




\section{DISCLAMMER}

Portions of this document may be illegible in electronic image products. Images are produced from the best available original document. 


\section{DISCLAIMER}

This report was prepared as an account of work sponsored by an agency of the United States Government. Neither the United States Government nor any agency thereof, nor any of their employees, make any warranty, express or implied, or assumes any legal liability or responsibility for the accuracy, completeness, or usefulness of any information, apparatus, product, or process disclosed, or represents that its use would not infringe privately owned rights. Reference herein to any specific commercial product, process, or service by trade name, trademark, manufacturer, or otherwise does not necessarily constitute or imply its endorsement, recommendation, or favoring by the United States Government or any agency thereof. The views and opinions of authors expressed herein do not necessarily state or reflect those of the United States Government or any agency thereof. 


\section{CONTENTS}

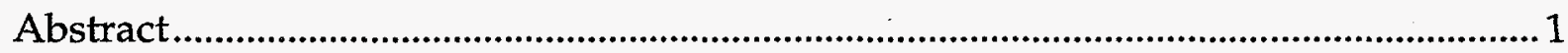

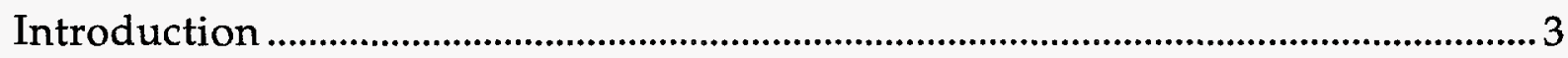

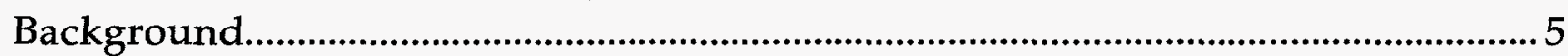

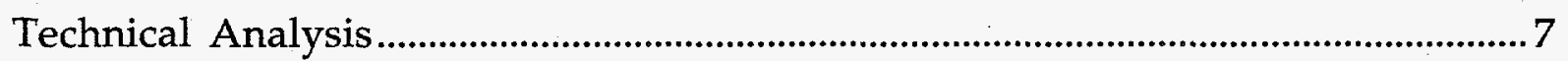

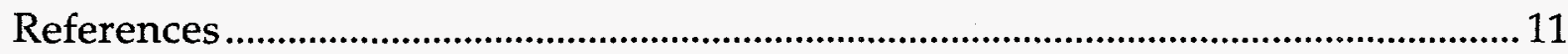




\title{
TECHNICAL BASIS FOR STORAGE OF ELASTOMER-SEALED PRODUCE CANS IN THE DOE-STD-3013-94 PACKAGE
}

by

David R. Horrel1, J. L. Stakebake, and R. W. Szempruch

\begin{abstract}
Department of Energy standard DOE-STD-3013-94 establishes criteria for the long-term packaging of plutonium metal and oxide. The inclusion of organic materials in sealed packages of plutonium may produce gases that contribute to container pressurization. To expedite processing, it would be desirable to permit, within the DOE-outlined criteria, limited amounts of organic materials to be used as a sealing gasket in some packaging containers. This paper presents a technical basis for allowing elastomer-sealed cans to be packaged inside the sealed inner container of a double weldsealed DOE-STD-3013-94 container system.
\end{abstract}




\section{INTRODUCTION}

The inclusion of organic materials in sealed packages of plutonium can form gases that contribute to internal container pressurization. In order to expedite processing, permitting limited amounts of organic material to be used as a sealing gasket is desirable in some packaging containers. The purpose of this paper is to provide a technical basis for allowing elastomer-sealed cans to be packaged inside the DOE-STD-3013-94 inner sealed container. 


\section{BACKGROUND}

Pressure generation during storage of plutonium remains one of the primary concerns associated with the long-term storage of sealed plutonium oxide packages. The source of any pressure build-up is associated with adsorbed species, organic materials (e.g., plastics), or the helium byproduct from the alpha decay of plutonium. Low-molecular-weight species, such as oxygen and nitrogen, dissociate and reform as gaseous products, such as nitrogen oxides. Heavier molecules tend to polymerize or decompose. Radiolysis of water is a reversible reaction producing oxygen and hydrogen. Products formed by radiolysis of plastics or other organic materials depend on the chemical composition of the source material and typically include mostly hydrogen. Radiolytic decomposition of molecular and organic species in a storage vessel may contribute to internal can pressurization. Gaseous radiolysis products will either react with the stored material and/or the storage vessel itself or will lead to pressurization.

Pressurization may be minimized inside oxide packages by minimizing organic packaging materials and by minimizing the amount of adsorbed contaminants, primarily water. Adsorbed materials are removed from the oxide by heating in order to desorb all of the adsorbed water and other gases. Heating to a temperature of approximately $1000^{\circ} \mathrm{C}$ also reduces the surface area of the oxide, resulting in fewer surface sites for readsorption. The effectiveness of this process is verified by a loss-on-ignition (LOI) analysis that measures the amount of volatile materials that remain or are readsorbed on the oxide after processing. The performance requirement for acceptable oxide is an LOI of $<0.5$ mass percent. 


\section{TECHNICAL ANALYSIS}

The sealant commonly used in cans manufactured by U.S. Can, Inc., and ELLISCO, Inc., is a compound that is known as Darex ${ }^{\circledR}$ and that is manufactured by W. R. Grace Co. (Dewey and Almy Division). Several forms of this material are essentially water-based sealants that contain rubber, filler, and antioxidants. Combustion of the sealant yields carbon dioxide and water. ${ }^{1}$

The amount of elastomeric material in a sealed 401-size can has been measured by both U.S. Can and W. R. Grace. The amounts varied from $88 \mathrm{mg}$ to $120 \mathrm{mg}$ (from $44 \mathrm{mg}$ to $60 \mathrm{mg}$ per seal). The amount of sealant on a 401 can may vary by $10 \%$ for different manufacturers. ${ }^{2}$

Studies of the radiolysis of various materials show that the main product of the radiolysis is hydrogen. Any oxygen present is rapidly reacted and disappears from the gas phase. ${ }^{3}$ Other gaseous products, such as carbon dioxide and nitrogen oxides, are insignificant. Most organic materials may be represented by $\left(\mathrm{CH}_{2}\right)_{n}$ Gaseous methane $\left(\mathrm{CH}_{4}\right)$ and ethane $\left(\mathrm{C}_{2} \mathrm{H}_{6}\right)$ are exceptions. A complete radiolysis of a "mole" of " $\mathrm{CH}_{2}$ " can form a maximum of 1 mole $\mathrm{H}_{2}$. Thus, for each gram of " $\mathrm{CH}_{2}$ " there is a potential for formation of

$$
\frac{1 \mathrm{~g}}{\frac{14 \mathrm{~g} \mathrm{CH}_{2}}{\mathrm{~mol}}}=0.071 \mathrm{~mol} \mathrm{CH}=0.071 \mathrm{~mol} \mathrm{H}_{2} \text {. }
$$

If $\left(\mathrm{CH}_{2}\right)_{n}$ is assumed to be part of the elastomer composition, $0.12 \mathrm{~g}$ (the maximum for a 401 -size can) would produce $0.0085 \mathrm{~mol}$ of hydrogen. At $50^{\circ} \mathrm{C}$ the 
elastomer from one 401 can would contribute an additional pressure of

$$
\mathrm{P}(\mathrm{atm})=(0.0085)(0.082)(323) / 2=0.113 \mathrm{~atm}=1.66 \mathrm{psi}
$$

to the pressure inside the 2-L inner sealed container of the DOE-STD-3013-94 package, which contains two sealed containers.

Equation 1 in Appendix A of DOE-STD-3013-94 provides a means for estimating internal pressures of sealed cans. Consider completely filling a sealed 2-L container with $4 \mathrm{~kg}$ of $\mathrm{PuO}_{2}$ that has a density of $2 \mathrm{~g} / \mathrm{cc}$ and an LOI of $0.5 \%$. In accordance with DOE-STD-3013-94, the calculated pressure at room temperature from radiolysis of $0.5 \%$ adsorbates would be about 365 psi. Admittedly, higherdensity oxides would result in higher pressures; and headspace above the oxide would lower the pressure. However, these variances would not significantly change the result. Thus, by comparison, the addition of elastomer seals on one can inside the sealed container would increase the pressure on the order of

$$
1.66 / 1.66+365=0.0045 \text { or } 0.45 \% \quad \text {. }
$$

This amount is insignificant.

An alternative approach to this evaluation assumes that for a worst-case analysis, all of the elastomer contained in a can would be volatilized. This pressure increase would be equivalent to increasing the measured weight loss (LOI) to $0.120 \mathrm{~g}$ per can. For example, consider a DOE-STD-3013-94 package containing $1000 \mathrm{~g}$ of oxide in a sealed 401 produce can ( $0.12 \mathrm{~g}$ elastomer). In order to meet the $0.5 \%$ LOI criterion, the measured LOI must be less than $4.88 \mathrm{~g}$. The total LOI for the 1000-g package would become

$$
\mathrm{LOI}=4.88 \mathrm{~g}+0.12 \mathrm{~g}=5.00 \mathrm{~g}=0.5 \%
$$


The pressure contribution from the limited amount of elastomer used to seal produce cans does not present any concern with respect to pressurization of sealed DOE-STD-3013-94 containers and need not be accounted for.

Should more than the nominal organic material associated with produce cans need to be evaluated, Equation 1 in Appendix A of DOE-STD-3013-94 provides the basis for this calculation. The second term in the equation represents the pressurization resulting from the complete radiolysis of adsorbates. This term is derived from the ideal gas law

$$
P=\frac{n R T}{V}
$$

in which $n$ is the number of moles of gas formed from radiolysis, $P$ is pressure, $V$ is volume per mole of gas, $T$ is temperature, and $R$ is the gas constant. To provide a bounding pressure calculational basis for DOE-STD-3013-94, the values for $n$ reflect $1.5 \mathrm{~mol}$ gas $\left(\mathrm{H}_{2}+0.5 \mathrm{O}_{2}\right)$ formed for every mole of $\mathrm{H}_{2} \mathrm{O}$ (the assumed adsorbate) radiolyzed.

When one considers $1 \mathrm{~g}$ of $\mathrm{H}_{2} \mathrm{O}$, the result is

$$
\frac{\frac{1 \mathrm{~g}}{18 \mathrm{~g} \mathrm{H}_{2} \mathrm{O}}}{\mathrm{mol}}=0.055 \mathrm{~mol} \mathrm{H}_{2} \mathrm{O}
$$

Each mole of water can form $1.5 \mathrm{~mol}$ of gas $\left(\mathrm{H}_{2}+0.5 \mathrm{O}_{2}\right)$, so the $1 \mathrm{~g}$ of $\mathrm{H}_{2} \mathrm{O}$ could form $0.083 \mathrm{~mol}$ of gas. Because the number of moles of gas formed from water $(0.083 \mathrm{~mol} / \mathrm{g})$ is greater than that formed from an equivalent mass of " $\mathrm{CH}_{2}$ " organic compounds ( $0.071 \mathrm{~mol} / \mathrm{g})$, any amount of organic compound may be in the container, provided the weight does not exceed the $0.5 \%$ LOI limit and does 
not jeopardize the basis upon which the standard (DOE-STD-3013-94) was established. Stated simply, if the LOI of the material in the container plus the equivalent LOI from organic compounds associated with the packaging (e.g., elastomer seals and oil film) is less than $0.5 \%$, then the design basis for the container is maintained.

If an option for elastomer sealing were selected, a gross LOI for the package should be established and recorded as part of the container data package. As a general rule, inclusion of any organic materials in sealed containers should be avoided. 


\section{REFERENCES}

1. Material Safety Data Sheet, Darex Experimental Compound AD 23118 LS, W. R. Grace Co., Dewey and Almy Division, Lexington, Massachusetts ( June 11, 1991).

2. "Film Weight" Information File No. CCS CN, U.S. Can, Inc., Baltimore, Maryland (April 1990).

3. Armen R. Kazanjian, "Radiolytic Gas Generation in PlutoniumContaminated Waste Materials," USDOE Report RFP-2469 (October 1976). 
